\author{
Liliia Varchenko-Trotsenko \\ $\mathrm{PhD}$ (pedagogical sciences), Researcher of IT in Education Laboratory \\ Borys Grinchenko Kyiv University, Kyiv, Ukraine \\ l.varchenko@kubg.edu.ua \\ ORCID: 0000-0003-0723-4195
}

\title{
Viktoriia Vember
}

$\mathrm{PhD}$ (pedagogical sciences), Associate Professor of the Department of Computer Science and Mathematics Borys Grinchenko Kyiv University, Kyiv, Ukraine

v.vember@kubg.edu.ua

ORCID: 0000-0002-4483-8505

\section{Tetiana Terletska}

Junior Researcher of IT in Education Laboratory

Borys Grinchenko Kyiv University, Kyiv, Ukraine

t.terletska@kubg.edu.ua

ORCID: 0000-0002-8046-423X

\section{MAIN ASPECTS OF EDUCATIONAL VIDEO MATERIALS DESIGN FOR USE IN EDUCATIONAL PROCESS OF HIGHER EDUCATIONAL INSTITUTIONS}

\begin{abstract}
One of the modern trends in both formal and corporate education is microlearning which involves using short videos in educational process. Microlearning has a variety of advantages including that this approach is more student-oriented, aimed at increasing the level of mastering knowledge, requires less time spent by students for learning, gives a possibility to study at any time and anywhere using own devices, increases motivation etc. The article deals with methodological aspects of creating educational video materials taking into account psychological peculiarities and learning habits of modern students. Video materials belong to the most powerful tools in educational process as they provide students with the possibility of simultaneous perception of auditory and visual information. Video materials must be strictly structured and involve students into learning process, in particular they could be included into different sources of electronic learning courses (ELC). There are different types of videos that are used in ELC such as introductory video, video lectures, video tutorials, additional video materials, interactive video. In spite of content variety all video materials undergo the same procedure of creation including dividing material into logically finished parts, notions definition, writing content questions, components structuring etc. Recording of a video must be a thoroughly planned process to ensure high quality of outcoming product. The article also deals with peculiarities of webinars as one of the possibilities of using video materials in educational process of higher educational institutions. Different types of webinars are analysed including tutorial webinar, lecture webinar, practical webinar.
\end{abstract}

Keywords: video materials; microlearning; video lecture; video instruction; webinar; higher education

Introduction. Education and higher education in particular is a background for individual growth and social progress which furthers economical development, growth of people's level and quality of life. As a result of transformation of education a role of academic staff is changing.

Antonio dos Reis notes that teachers should update their technological and methodological skills according to the needs of the students' profile. This requires permanent training in such areas as:

- online tutoring on the use of virtual classrooms, video conference tools and virtual group work;

- the use of tools to produce contents in multimedia format, pedagogic games, the use of interactive synchronous and asynchronous tools;

- the use of interactive synchronous and asynchronous tools;

- ability to use online platforms for managing contents (LMS) and other supporting interactive animations like 3D and MUVES etc. (Reis, 2015). 
Thus, a modern academic has to be able to choose and use digital resources for teaching students, organise collaboration and communication among all participants of learning process, design electronic resources and educational learning environment, be facilitator and assistant for students, understand well and consider their needs and peculiarities in learning process, cognitive learning styles, new services and instruments for effective communication and collaboration, possess 21 st century skills, consider modern educational trends in their activity.

Microlearning belongs to modern trends both in formal and business education (Sanal, 2018). Providing learning materials in the form of short learning videos has such advantages for students as more learner-centric approach, increases knowledge retention, less time-consuming, enables learning on the go, improves motivation etc.

To the peculiarities of microlearning belong division of learning materials into micro modules five to ten minutes each, easily renewable content, increase of profitability, determination of understandable gaps in students' knowledge, possibility to react quickly to change of learning materials depending on students' feedback received in the learning process, speedwork (Morze, Varchenko-Trotsenko, 2019).

Academics of higher educational institutions widely use video materials in the process of preparation to their lectures, designing practical tasks and electronic learning courses. Research of the problem of utilization of multimedia, audio and video technologies in educational process can be found in works of Yu. I. Verysokina, A. I. Kaptereva, O. V. Shlykova, Yu. P. Fedorenko, T. O. Iakhunova, K.Deshan-Potter, L. Klark, E. Dale, S. K. Diamond, L. Bents, E. Ramos. Scientists note that using learning and methodological multimedia materials promotes formation and development of communicative competence, increase of motivation to study a discipline, provides participation effect, interactivity, prompts to a dialog and is an inexhaustible source of learning materials (Vember, Buchynska, 2016).

Many educational materials including educational videos can be found open-source in the Internet. But they do not always match the goals and objectives of the lesson and their quality can be improper. That is why one of the characteristics of a modern academic is a skill to design high quality educational videos.

The aim of the is definition of methodological aspects of educational video materials design and webinar arrangement.

In Borys Grinchenko Kyiv University considerable attention is paid to implementation of electronic learning based on using electronic content (e-content) including electronic learning courses (ELC) and electronic collaboration (e-collaboration) technologies for all participants of educational process on the basis of designed electronic informational and educational environment of the University. By means of active implementation of electronic learning in Borys Grinchenko Kyiv University "Regulations on ELC: order of creation, certification and utilization in e-learning system of Borys Grinchenko Kyiv University (amended)" started working where it is stated that $50 \%$ of classes can be arranged remotely. And video materials play an important role in ELC. Let us define types of video materials that can be presented in ELC (Varchenko-Trotsenko, 2019):

- Introductory video (promo video). That is a short description of an ELC content to form general idea of the course for users.

- Video lectures: 1. Classroom lecture recording is a video recording of a traditional lecture of a course; 2. Micro lecture is an effective short video material prepared specially for ELC; 3. Webinar recording is a video recording of a webinar which was held by a lecturer.

- Video tutorials. These are references for practical and laboratory tasks etc.

- Additional materials. These are links on video materials from the Internet network ect (for example, videos by famous lecturers, video 360).

- Interactive video. This is implementation of branching scenarios of watching videos with a possibility to form own educational path. 
Let us present methodological aspects of creating the above mentioned types of videos.

Introductory video is a convenient way to present a lecturer and a course to students, outline main expectations from their performance and motivate them for future learning achievements. An average introductory video takes from two to five minutes. To ensure that all the necessary information is included into the video it is recommended to create an outline. The following information is advisable to be included into an introductory video:

- Welcome message introducing a lecturer

- Course title and its place in the curriculum

- Theoretical and/or practical importance of the course for students

- Structure of the course

- Expectations from students' performance

- Assessment peculiarities

- Special instructions for assignments if required

For introductory video both instructor at a desk and talking head types can be used. Moreover, it can be presented in the form of animation, video scribing etc. These types can be created with the help of such services as Powtoon, GoAnimate, Sparkol VideoScribe.

Video lecture is a way of presenting theoretical materials in the form of a video that matches predicted learning outcomes, reveals conceptual questions of a lecture and has logical, completed form.

This short video material of approximate length of six to nine minutes can be used in electronic learning course separately or as a part of lectures series on a definite topic aimed to provide students with theoretical materials. Video lectures can be used as elements of flipped learning and blended learning technologies arrangement and they contribute to rational use of a lecturer's time in the classroom.

Video lectures are divided into the following types:

1. Instructor at a desk

2. Talking head

3. Combination of the two above mentioned types and adding didactic video

Instructor at a desk type focuses on recording a lecturer. Any means of visualization (a flipchart, schemes, maps, volumetric models etc) play supporting role. While recording a video a lecturer can be sitting at a desk or moving in limited space (for example, stand near a flipchart).

Talking head type focuses on visual demonstration of materials and a lecturer performs a role of a commentator. A ready video contains briefly explained material in the form of a presentation and accompanying video comments of a lecturer providing comprehensive explanations of the slides.

Both types can be combined at the stage of video editing.

While getting ready to video recording of instructor at a desk type, a lecturer should prepare all the objects (schemes, pictures, models) that are required for demonstration in the video and write either a full-text scenario or short theses to help with voice acting during the recording. It is advisable to avoid vast explanations and complex language constructions as they make both recording process and perception by students more difficult. Previous rehearsals simplify recording and help to identify the problems at the preparation stage. A lecturer can train in front of a mirror to pay attention to facial expressions and gestures and use a dictaphone to track linguistic flaws: fillers-in, repetitions etc.

For videos of talking head type a lecturer has to prepare visual material in the form of a presentation or separate slides where the information will be given as short theses, schemes, spreadsheets, pictures etc. A place for a video with a talking lecturer must be planned unless the slide requires audio only. With a lecture prepared in the form of a presentation notes can be used as a prompter. It is important that the notes are shortened to not more than two or three 
sentences. Otherwise that would require scrolling which does not look very appropriate in the video. Lecture material must be divided into logically finished parts, each of those is preferably not longer than nine minutes.

A lecturer should wear bright clothes contrast to the background and combinable with the colours of the presentation. The makeup should be expressive but without glitter so that it did not sparkle in the light.

Video streaming has become one of the latest trends in higher education as there is a need of wider audience coverage than it is possible to place in one university auditorium especially when talking about honorary lecturers and top speakers in the scientific field. Additionally it is becoming more and more required with the growth of popularity of distance education. One of the most widespread forms of video streaming is a webinar (Ronchetti, 2011).

Methodological recommendations on arranging webinars

Webinar (web-based seminar) is a learning technology that helps to arrange educational events in sync and provides instruments for electronic collaborative work of participants through the Internet. The webinar technology can be used to organise online tutorials, interactive practical classes (seminars, laboratory classes) as well as for online conferences. All those events can be recorded if required. Participants of webinars can be located in different places as their collaboration is organised by using tools for audio and video data exchange and collaborative work with different objects online (Verma, Singh, 2010). To join a webinar participants have to use PCs, laptops, tablets or smartphones.

Depending on the aim webinars could be arranged for the following types of events:

- Tutorial

- Lecture

- Practical class or seminar

Tutorial webinar can be arranged as a personal room using a webinar tool where a student is able to communicate with a teacher or a project/thesis supervisor individually at a set time. It can be used for group guidance as well. The options of single use as well as permanent link are available. Therefore, a choice of a tool for a tutorial webinar depends on the number of students simultaneously connecting to the webinar, necessity of repeated consultations and materials used for demonstration. Taking into consideration that a tutorial webinar typically requires double-sided communication students should be provided with means for audio and (if required) video interaction (e.g. headset, camera, software etc.), possibility of materials exchange.

A teacher can also use a personal room as an instrument for recording webinars for further utilization in electronic learning courses (Morze, 2014).

Lecture webinars are used for arranging online speaking engagements for wide audience. A lecturer must be able to show a presentation, demonstrate the screen as well as viewed and heard by participants. The choice of a tool for webinar in this case depends heavily on the number of participants as a lot of software for webinars have limitation in that matter. Required options also have to be considered at the stage of a tool choice. If a lecturer expects to receive feedback on any question, especially for wider audience, a function of creating a poll should be foreseen. For smaller groups a chat could be used for the same purpose. It is also useful when a tool for webinars can be integrated with a calendar so that all the participant could receive a notification before the event automatically.

Lecture webinars belong to the ones that are most frequently used after the event both by the teacher to provide with the information other groups of listeners and by students who could not be online at the time of the webinar. Therefore, it is essential that a tool chosen for such type of webinar had a recording option.

Interactivity and continuous communication play an important pedagogical role in arrangement of seminars and practical classes in the form of webinars. Interactivity can be 
provided with the help of different online instruments implemented into a webinar platform. Among them there are tests, online polls, discussions visualization, group work, files exchange, recording and sharing content of a webinar.

Theme and content of a webinar. It is important to formulate a precise content of a webinar and send it together with invitations to join the webinar to participants to inform about the questions which will be considered during the webinar. That will help the participants get ready for the event as well as make a research on the topic and prepare question for the lecturer.

Tests for webinar. Tests belong to the instruments that contribute into interactivity of online events. A lecturer could use them at any time during a webinar: before the start they would help to actualize participants' knowledge on the topic; in the middle or at the end of a webinar they are used to check a level of gained knowledge. It is recommended that questions for tests were prepared in advance so that all technical settings could be applied before a webinar and did not take time during the event. The number of questions should be limited and the questions themselves should not be massive to avoid the risk of turning the webinar into online testing. The time required for testing must be considered while preparing to the webinar, so the questions have to be formulated in the way they did not require vast answers.

Online polls for receiving participants' feedback. A poll can be arranged during or after a webinar where all participants have to answer one or several questions. A poll can be carried out to actualize participants' knowledge on the topic, to sum up learnt materials or to motivate listeners to participate actively in the webinar. Some tools for webinars allow also recording results of polls for further downloading and utilization. Introduction of polls during webinars requires thorough planning of time for answers, clear and unambiguous formulation of questions prepared in advance.

Visualization is one of the most important methods of delivering information during webinars. It can be provided through sharing a presentation as well as demonstration of screen or separate applications. A lot of software for webinars offer also a Whiteboard tool where a lecturer is able to write notes or paint something during a webinar. In addition, there could be options which allow participants to share their materials. The possibility must be considered at the stage of a webinar preparation and the presenter must inform the participants about required materials and their format in advance as well as choose appropriate software which allows arrangement of all necessary options. Attention is to be paid to the size of files as it is possible that some of the participants could be using devices with lower speed of the Internet connection and would not be able to download corresponding materials. That means that the size of shared files must be limited. The same refers to the formats of files. It is important to use widespread formats such as .pdf, .ppt, .doc(.docx), .jpg, .png and others which can be opened on most devices without installing additional software. The time for participants' performance must be included into timing of the webinar. A lecturer has to be specific in formulation of tasks. It is advisable to encourage participants to react to the speech and visualization using a chat or corresponding graphic object (such as "thumb up", "speed up", "slow down" etc.) tools.

Group work can be considered as one of the parts of a webinar if the number of participants allows to arrange that. This type of assignment is suitable for smaller number of listeners with a defined list of members so that a lecturer could divide them into groups. While getting ready for such type of collaboration a presenter must carefully plan time for each task, prepare detailed instruction for work and decide on the forms of presenting results of group work. The tasks for the groups could be the same or different depending on the aim of the work. To save time it is possible to separate parts of one project among the groups and unite the results at the end of the session.

Webinar recording. Most tools for webinars allow recording events fully or partly. This function is important both for lecturers and participants as it provides them with a possibility of repeated watching. A lecturer can use it for analysis and further improvement of the webinar 
as well as for sharing with other listeners. The participants are able to return to the information which requires refreshment or deeper studies or use it for preparation for some form of control. The main advantage of a recorded webinar is that it can be viewed at any time and regardless of a viewer' s location.

Corresponding software is required in most cases for arrangement of a webinar. But installation of additional software is mostly optional to take part in a webinar.

Adding video materials in ELC

To make further utilization more convenient it is advisable to upload a video on Youtube and afterwards add it into an e-learning course. We provide examples of ways of adding videos into e-learning courses below:

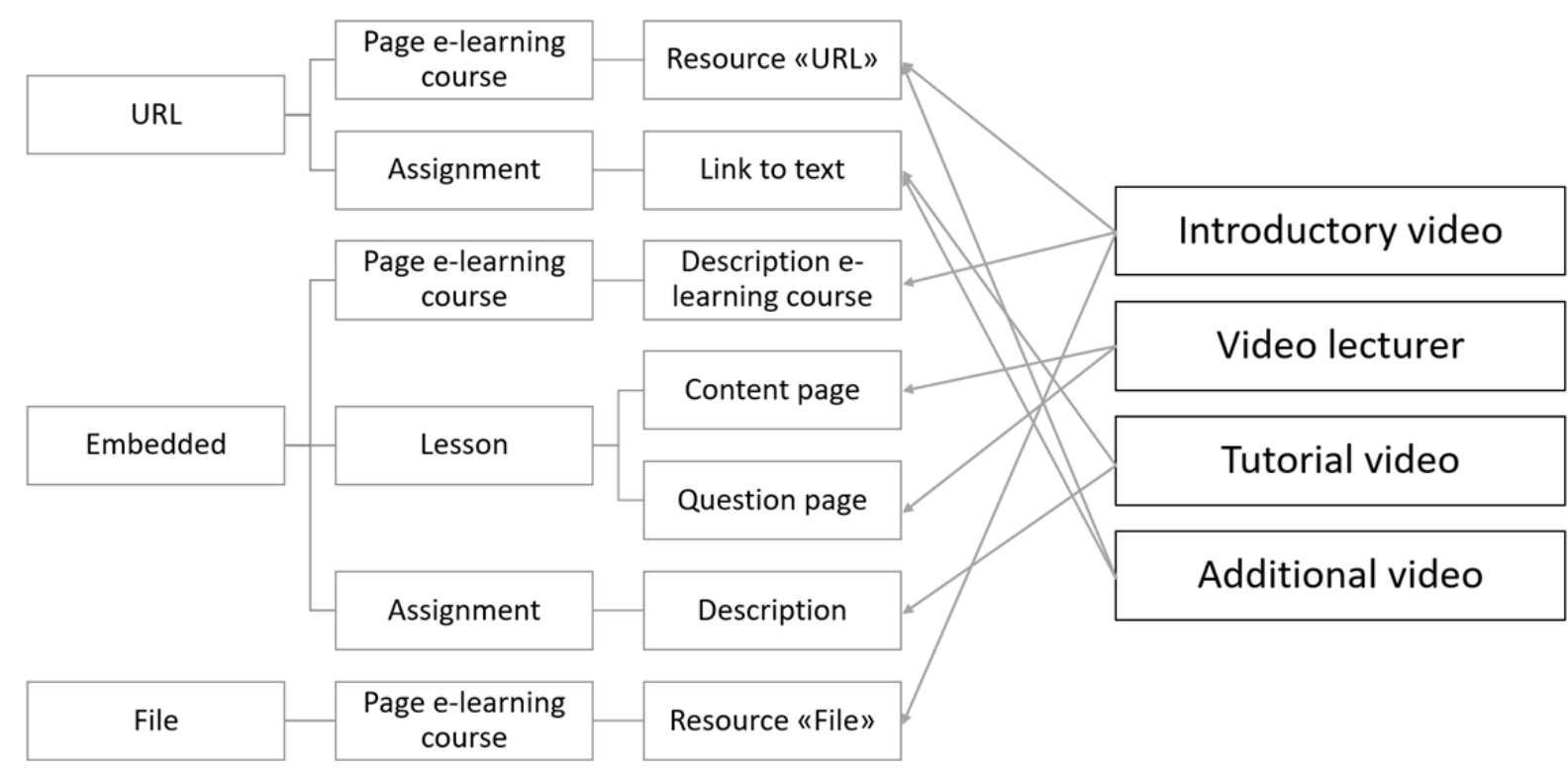

Fig.1. Options of adding video into e-learning course

A teacher chooses the most convenient way for every individual case.

Conclusion. A modern teacher of a higher educational institution has to be able to design electronic resources and electronic educational environment, understand well and consider in learning process needs and peculiarities of the students, cognitive learning styles, new services and instruments for effective collaboration, communication and possess 21 st century skills, consider modern educational trends in their activity including microlearning. In the process of designing own video materials a teacher should consider that all video materials must be designed considering cognitive features of modern students who frequently switch their attention and read less which means that videos have to be short. Also a teacher has to be ready to create high quality video materials and be able to organize electronic collaboration and communication of students.

Further research perspectives are aimed at research of attitude of Borys Grinchenko Kyiv University academics to designing own video materials for electronic learning courses, difficulties they face in the process and ways of their overcoming.

\section{Acknowledgements}

The research leading to these results received, within the framework of the Modernization of Pedagogical Higher Education by Innovative Teaching Instruments. MoPED - KA2 CBHE - 586098-EPP-1-2017-1-UA-EPPKA2-CBHE-JP. This publication reflects the views only of the authors, and the Commission cannot be held responsible for any use which may be made of the information contained therein. 


\title{
REFERENCES
}

Reis, A. (2015). How to be a teacher in the 21st century. Open educational e-environment of modern University, 1. doi:10.28925/2414-0325.2015.1.201t06

Sanal, A. (2018). 5 Benefits of Microlearning - Employees and Organizations. October 28, 2019.

https://playxlpro.com/five-benefits-of-microlearning

Morze, N. \& Varchenko-Trotsenko, L. (2019). Use of flipped learning technologies on the base of video materials. Scientific journal of NPU Dragomanova. Series Nr. 2. Computer oriented learning systems, 21 (28), 9-17. (in Ukrainian)

Vember, V. \& Buchynska, D. (2016). Modern types of educational videos and peculiarities of their use in the educational process. Educational discourse, 1(13), 19-29. October 22, 2019.

http://od.kubg.edu.ua/index.php/journal/article/view/348/289 (in Ukrainian)

Varchenko-Trotsenko, L., Tiutiunnyk, A. \& Terletska, T. (2019). Using video materials in electronic learning courses. Open educational e-environment of modern University, Special Edition «New Pedagogical Approaches in STEAM Education». October 28, 2019. doi:10.28925/2414-0325.2019s34

http://openedu.kubg.edu.ua/journal/index.php/openedu/article/view/253

Ronchetti, M. (2011). Perspectives of the Application of Video Streaming to Education. In Ce Zhu, Yuenan Li, Xiamu Niu, Streaming Media Architectures, Techniques, and Applications: Recent Advances, Hershey PA, USA: Information Science Reference, IGI Global, 411-428.

Verma, A. \& Singh, A. (2010). Webinar - Education through Digital Collaboration. Journal of Emerging Technologies in Web Intelligence, vol.2, 2, 131-136.

Morze, N., Kocharian, A. \& Varchenko-Trotsenko, L. (2014). Webinars as a Means to Professional Development of Teachers. Information Technologies and Learning Tools, 4(42). doi:10.33407/itlt.v42i4.1107 (in Ukrainian)

\section{ОСНОВНІ АСПЕКТИ СТВОРЕННЯ НАВЧАЛЬНИХ ВІДЕОМАТЕРІАЛІВ ДЛЯ ВИКОРИСТАННЯ В ОСВІТНЬОМУ ПРОЦЕСІ ЗАКЛАДІВ ВИЩОЇ ОСВІТИ}

\author{
Варченко-Троценко Лілія Олександрівна, \\ кандидат педагогічних наук, науковий співробітник НДЛ інформатизації освіти \\ Київський університет імені Бориса Грінченка, Київ, Україна \\ l.varchenko@kubg.edu.ua \\ ORCID: 0000-0003-0723-4195
}

\section{Вембер Вікторія Павлівна,}

кандидат педагогічних наук, доцент, доцент кафедри комп'ютерних наук і математики факультету інформаційних технологій та управління

Київський університет імені Бориса Грінченка, Київ, Україна

v.vember@kubg.edu.ua

ORCID: 0000-0002-4483-8505

Терлецька Тетяна Сергіївна,

молодший науковий співробітник НДЛ інформатизації освіти

Київський університет імені Бориса Грінченка, Київ, Україна

t.terletska@kubg.edu.ua

ORCID: 0000-0002-8046-423X

\begin{abstract}
Анотація. Одним з сучасних трендів як в освіті, так і для організацій, є мікронавчання, що передбачає використання коротких відео в освітньому процесі. Мікронавчання має ряд переваг, зокрема це підхід, більше орієнтований на студентів, спрямований на підвищення
\end{abstract}


рівня засвоєння знань, вимагає менше часу на навчання у студентів, надає можливість навчатися будь-коли та будь-де 3 використанням власних пристроїв, покращує мотивацію тощо. У статті розглянуто методичні аспекти створення навчальних відеоматеріалів, враховуючи психологічні особливості та навчальні звички сучасних студентів. Відеоматеріали належать до найпотужніших інструментів в освітньому процесі, оскільки вони забезпечують одночасне сприйняття учасниками навчання аудіальної та візуальної інформації. Відеоматеріали для мікронавчання мають бути чітко структурованими та залучати студентів до освітнього процесу, зокрема вони можуть бути включені до різних ресурсів електронних навчальних курсів (ЕНК). Існують різні типи відео, що використовуються в ЕНК, такі як вступне відео, відео-лекції, відео-інструкції, додаткові матеріали, інтерактивні відео. Не зважаючи на різноманітність контенту, всі відеоматеріали проходять однакову процедуру створення, що включає: поділ матеріалу на завершені частини, визначення понять, написання змістових питань, структуризація компонентів тощо. Створення відео для електронного навчального курсу має бути чітко спланованим процесом, щоб забезпечити високу якість вихідного продукту. В статті також розглядаються особливості вебінарів як можливості використання відеоматеріалів в освітньому процесі закладів вищої освіти. Проаналізовано різні типи вебінарів, зокрема вебінар-консультація, теоретичний вебінар, практичний вебінар.

Ключові слова: відеоматеріали; мікронавчання; відео-лекція; відео-інструкція; вебінар; вища освіта 